\title{
Women's Need Of Men In Danielle Steel's First Sight
}

\author{
Yusqi Qolbi, Ikwan Setiawan, Supiastutik \\ Jurusan Sastra Inggris, Fakultas Ilmu Budaya, Universitas Jember \\ Jln. Kalimantan 37, Jember 68121 \\ E-mail: yusqi1996@gmail.com
}

\begin{abstract}
This study aims to determine and analyze women's choices in the novel First Sight. This research focuses on the role of women who have high careers, and at the same time have feminine characteristics in themselves. Post-feminism theory is used to analyze elements related to women's choices in novels. This novel tells the story of a successful woman who tries to face and transcend her past in love as the background of the story. It shows the point of view of a successful woman in conquering her fears and getting her soul mate. Through this novel, Danielle Steel teaches us that women can have high careers and at the same time apply femininity to themselves. On the other hand, Steel also wants to answer women's concerns about women and mothers who have high careers in society.
\end{abstract}

Keyword: First Sight, Gender, Post-feminism, self-expression, Sexuality, Subjectivity, Women

\section{Preliminary}

First Sight was written by Danielle Steel and it was first published in the United States in 2013 by Delacorte Press. In this novel she add some of her real life experience into the story. This makes First Sight become one of her prolific novel.

The novel tells about how a woman with a successful career still need the existence of life partner to keep her going. It shows how women manage their womanliness when they are given the freedom of self-expression which.

Here, I used Post-feminism theory by Luce Irigaray. She is one of the French feminists most interested in the concept of difference: differences between the sexes; differences among women; differences within the single individual woman. ${ }^{1}$ This thesis is using Irigaray's theory of Post-feminism about women's femininity since Danielle Steel, the author of First Sight through the main character in the story, has her individual perspective on what is feminine, when it comes on relation to femininity Irigaray also has her own statements. She mentioned that 'feminine is defined as something which does not constitute a sexual heterogeneous but rather represents a type of negativity that sustains and confirms the homogeneity of masculine desire. ${ }^{2}$ In its relation

\footnotetext{
${ }^{1}$ Charles M. Brooks and Janice L. Ammons, "Free Riding in Group Projects and the Effects of Timing, Frequency, and Specificity of Criteria in Peer Assessments," Journal of Education for Business 78, no. 5 (May 1, 2003): 23, https://doi.org/10.1080/08832320309598613.

2 Diana J. Fuss, “'Essentially Speaking': Luce Irigaray's Language of Essence,” Hypatia 3, no. 3 (ed 1988): 63, https://doi.org/10.1111/j.1527-2001.1988.tb00189.x.
} 
with post-feminism, Irigaray agrees with the concept that a woman should have the eternal feminine aspect in her mind and body.

Irigaray claimed some points about language indirection in her I love to you. ${ }^{3}$ According to her, it is crucial that women learn to occupy the position of "I" and "you" in language. Irigaray views that "I" and the "you" as markers of subjectivity. She describes how that woman does not occupy the subject position. ${ }^{4}$ It is clearly stated in her book that by saying 'I love to you' it means one is respecting the other. "I love to you means I maintain a relation of indirection to you. I do not subjugate you or consume you. I respect you (as irreducible). ${ }^{5}$ However, she also tries to persuade woman that a woman can also own the subject position.

Irigaray's theories above show that she has the thought that a woman should be feminine and womanly, as it is also the goal of postfeminists. She also tries to show that woman has choices in her life, although a woman's nature is already described by the male systems of representation.

\section{Method}

This research is a qualitative research because it involves collecting and analyzing nonnumerical data (e.g., text, video, or audio) to understand concepts, opinions, or experiences. Denzin and Lincoln (year) stated that "qualitative research is multi-method in focus, involving an interpretive, naturalistic approach to its subject matter. This means that qualitative researchers study things in their natural settings, attempting to make sense of or interpret phenomena in terms of the meanings people bring to them. Therefore, this research focuses on collecting information's in the form of sentences and paragraphs from First Sight which later analyzed using postfeminism theory to find women subjectivities inside the novel.

The main source of the data used in this research is a novel entitled First Sight written by Danielle Steel. The data in this research are collected using the document technique which consist examining existing data in the form of sentences and paragraphs about female subjectivities. The data collected using the documentary technique are the sentences and paragraphs which talks about the topic of this research about the women needs of men and female subjectivities. The primary data are facts and information about the main character's role as the subject in a society and in her relationship with her partner. The secondary data are based on the literary research references by selecting related books, literary work reviews, and several data from e-resources in the form of printed packed-paper and the other is typed in electronic form which related to the struggle of woman to stand her ideologies.

There are several steps that has to be taken in doing this research such as close reading, classifying the data, analyzing the data, and make a conclusion. The first step is close reading. It means that I will read the novel more than once in order to get deep understanding about the text and the context. In this step, I will find the problem existed in the novel which later become the issue that the author want to presents.

Secondly, I will classify data taken from the novel First Sight which talks about women's subjectivities. Then, I will analyze them using post-feminism theory by Luce Irigaray. The last step is drawing conclusions from the research. The analyzing process of the research will be explained below.

There are several steps in answering the research questions. The first question is related to how the novel construct woman's choice through the female main character. The analysis focus on how the novel construct women's choice through the female main character. I use postfeminism theory by Luce Irigaray which focused on freedom of woman's choice. First, I will look

\footnotetext{
${ }^{3}$ Fuss, “'Essentially Speaking.”

${ }^{4}$ Fuss, 109-13.

${ }^{5}$ Fuss, 109.
} 
for sentences or paragraphs that talk about women's freedom in making choices. Then I will analyze it using the theory of postfeminism which shows the freedom of women in expressing themselves. This leads to their freedom to participate in both private places and public spaces in society.

The second question related to the contextual condition of women in United States around 2012 to 2013. In order to answer the question, it is necessary to know first about the position of women in the novel. That way, it can be notice which one that belong to the condition of American women in 21th century. Then, I analyzed the sentences and paragraphs in the novel which I connected with the conditions of 21 st century women and by doing so I could find the context of the writing of this novel. The last research questions explores the critical position of the author. It is related to whether the author agree or disagree to the issue existed in the novel. It can be seen through the selected dialogues and statements in the novel which shows the author's attitude towards the problem being discussed in the novel. After answering all three questions, I will make several conclusions about the research. It can answer the problems in shorts explanation. In addition, it contains some statements related to this whole research which is understandable. Then it can help other researcher who is interested in using the post-feminism theory by Luce Irigaray.

\section{Result}

Working woman are now a common thing in America. Single woman, married woman, and even a mother are now working at the same field as men. Being feminine and have domestic aspects in them are now considered to be good. They had the freedom of choices whether to be single or married, finding a job and go to work or become domestic housewife or even both at the same time. The thing is day by day things are started to change. Gender equality have been achieved and things which is in the past are considered as products of men's power are now seen as a value of a good woman, especially woman on being domestic. They are free on managing their womanliness and femininity. Being a woman and being a man have their own plus and minus and they were created so that woman and man could complete each other.

\section{Discussion}

\section{The Construction of Woman's Choice in First Sight}

First Sight tells us about the freedom of women's choice. The choice which is made by the female main character to become a successful fashion designer and domestic women at the same time. She became a fashion designer because she likes to make clothes. She wants to keep her feminine nature because she likes to feel domestic which means she likes to be pampered by her partner. She also became a person who liked children because she was also a mother and had a son. The freedom of women's choice is the impact of women's right of self-expression. The right of self-expression for woman is the ideology of postfeminism. Postfeminism can be understood as a form of rebranding for feminism by continuing to support women but giving up the politics and claims of self-empowerment. ${ }^{6}$ and replacing it with the right of self-expression. ${ }^{7}$ The right of self-expression give women the freedom to choose their way of life as they see fit.

\footnotetext{
6 "Fifty Key Concepts In Gender Studies /Jane Pilcher, Imelda Whelehan | PERPUSTAKAAN UNIVERSITAS TERBUKA," 105-6, accessed July 16, 2021, http://opac.ut.ac.id/detailopac?id=19618.

7 Joseph Elie Alagha, Hizbullah's Identity Construction (Amsterdam: Amsterdam University Press, 2011), 289.
} 


\section{Women as Both Subject and Object}

Danielle Steel through the female main character would like to convince the readers that wealth alone does not guarantee you a happiness, but being with the person you love the most is also important to complete the recipe of happiness. "He talked me into it, and into marrying him, to have kids. It turned out it was the best thing I ever $\mathrm{did}^{8}{ }^{8}$ This quotation describes that marriage is related to having a child, a fruit of the love from a couple, which means that marriage is obviously the facility to commit into a reproduction activity in order for the married couple to have a child.

Timmie accepts that her marriage with her late husband was the best thing she had ever done and from that marriage, she was gifted with a son named Mark. She accepts her nature as a woman which is included in marriage to be a mother, a vessel for a man to give her his seed so that they could have a descendant. This means that as a wife, a woman should serve her husband well. It means that women are expected to be faithful to the house jobs. This idea represented through the female main character when Timmie asks Zack about what he wants to eat because she will cook for him which made her feel domestic and she likes it.

So, women who have the right of self-expression can choose their life as they fit. If they want to take themselves as the subject of a relationship, they can go ahead and do it. They can become a working woman with a successful business and have huge earnings from it. They can also choose to become a housewife who liked to be loved by her husband and child, take care of them, and love them as much as she could. They will be valued culturally, socially, and economically by having this motherhood feeling in them. They could also choose to be both of them. They can have a successful career while at the same time take care of their husbands and children.

\section{Motherhood and Domestic Women}

Timmie's successful and wealthy life was not something that suddenly happened by itself. Before she achieved this extraordinary success Timmie had gone through various trials in her life. When Timmie was 5 years old she was abandoned by her parents. She was then placed in an orphanage and spent her childhood there. After she grew up and married, she was blessed with a child who she named Mark. However, Mark at that time suffered from cancer and medical technology at that time could not cure him. Timmie feels deeply saddened by the death of her child because he is the only child she has. Plus, she found out that her husband was bisexual and she had fallen in love with a man. Sometime after Mark's death her husband then left her. This adds to a series of bad events that happened to her and her family. As a result, Timmie got a trauma that made him afraid to lose someone he loved and fear to live alone. But, it doesn't stop her from believing that someday the right man will come for her even if the chance are very low knowing her age and status in the society.

Because Timmie once lost a child, she became a person who likes children. She always talks to children she meets in public places. Her way of communicating with children has gone beyond the boundaries of language and nationality. She has an attitude that can bridge the age gap between her and the children. Even children can feel that Timmie is someone who likes them. She has an easy way to talk to them. This skill is something that is unusual for someone who has a career and a position like her, moreover she also doesn't have children. Here, Steel

8 "Bantam Press," 104, accessed July 16, 2021, https://www.penguin.co.uk/company/publishers/transworld/bantam-press.html. 
shows that women who have high careers and positions in society can have a feminine element in them. She shows this through the main character in this First Sight novel. The main character has a high position and career, but she is someone who likes children. She had told her assistant several times that she might someday want to adopt a child. She always thought that she was alone in this world and to reduce it she wanted to have a life partner whether it was a man who could love her as she was or a child she could care for.

\section{Contextual Condition Related to Gender Condition in American Society}

The novel by Danielle Steel, entitled First Sight, was published in 2013. I wanted to know the background of the writing of this novel, so I looked for information about gender conditions at that time. I found that at that time many women were successful in achieving high-profile careers and becoming leaders of large companies. They consist not only of women from the younger generation but also women who are married and have children. At that time, American women are far more likely to work full time and rise to the top levels of business, academia, and professional fields like law and medicine than women in other developed countries. According to a recent study by Cornell University economists Francine Blau and Lawrence Kahn. ${ }^{9}$ American women are about as likely as American men to be company managers, while women in the researchers' comparison group of 10 other developed countries were only half as likely as men to have made it that far. In fact, the United States has the highest proportion of women in senior management positions of any country in the Organization for Economic Cooperation and Development (OECD), a grouping of the world's most developed countries. At 43 percent, it is a percentage that comes close to women's 47 percent overall share of the U.S. labor force. Women-owned business in America are now the fastest growing segment of the small business sector with the number of female run businesses growing faster than businesses owned by men throughout the 1990s and into the 2000s. ${ }^{10}$ The U.S. labor market is less segregated by sex than those of other economically advanced countries, with more women breaking into traditionally male fields. What's more, American women are more likely than European women to start and run their own businesses; some 46 percent of American firms are owned or co-owned by women, and the rate of female ownership is increasing at one and a half times the rate of overall business growth. That's why Danielle Steel gave the background to the main female character in First Sight as a successful businesswoman. This was done to describe the situation of women in America at the time Steel wrote the novel.

All of this talk about working woman and working mother have a connections with how Timmie who is a CEO of a fashion company wants to find her true love and have a child on her age which is at 48 years old where it is almost impossible for her to have a child and knowing her position in her career it is rare and hard to find a man who wants to be with her without using her. It is known that Timmie is a working woman and have a successful career. She then married and had a child whom she named Mark. After her son's death she and her husband made a decision to have a divorce because her husband is bisexual and marries her only to have a child. Before she become who she is now she was already an independent women.

"Considering how successful she was, Timmie was surprisingly unspoiled. She never forgot her simple origin, the luck that had started her on her career, or the coffee shop where she'd worked as a waitress, when she worked on her first designs at night, and bought inexpensive

\footnotetext{
${ }^{9}$ Francine D. Blau and Lawrence M. Kahn, "Gender Differences in Pay," Journal of Economic Perspectives 14, no. 4 (December 2000): 75-99, https://doi.org/10.1257/jep.14.4.75.

${ }^{10}$ Karyn Loscocco and Sharon Bird, "Gendered Paths Why Women Lag Behind Men in Small Business Success,” Work and Occupations 39 (May 1, 2012): 183-219, https://doi.org/10.1177/0730888412444282.
} 
and unusual fabrics with her tips. She had been making clothes for seven years, before her first big break at twenty-five, when a buyer from Barney's noticed some of the clothes Timmie had sold to her co-workers, which were kicky, fun, stylish, and exquisitely made.

She bought half a dozen of Timmie's best designs and took them back to the old Barney's store on West 17th Street, long before they moved uptown, and they were an instant hit. Her next order was twenty-five pieces, then fifty. When the buyer ordered a hundred pieces the following year, Timmie quit the coffee shop, rented a crumbling warehouse in L.A. fashion district and hired a dozen girls from an unwed mothers' home to help sew. ${ }^{11}$

Here, Steel describes how the female lead character struggles in her life after she is old enough to work. Timmie, who is now very successful, never forgets the origin of her success. She initially worked as a waitress in a coffee shop. While working there, she started her clothing business by selling it to her friends at the coffee shop. Then, someone who has a boutique shop is interested in the clothes she makes. Since then her clothing business has grown gradually until finally, she has become a successful fashion designer. It shows how women are given freedom in living their lives. Because gender equality is considered to have been achieved, Steel explains through the main character in her novel that women can become active subjects in society.

First Sight was published in 2013 by Delacorte Press. ${ }^{12}$ At the time this novel was published, many women at that time had started working and had high careers. They not only consist of women from the younger generation but some of them even have children. As one of the writers in pewresearch.org, Drake says that mothers are now the breadwinners of $40 \%$ of American homes. A breadwinner mother is a woman who earns as much or more than her partner or a single mother who provides a single income for her family. This proves that women can marry and have children as well as work to support their families and advance their careers.

\section{The Critical Position of the Author in the Novel}

In order to show the critical position of the author represented in the novel, I look for the background of the author who is an American. She is the portrayed of an American woman as the main female character in her novel. I also connect the issue in the novel with discourse of women's need of men. Her position is important, whether she agrees with the women's character act or criticizes the women's character act in the novel.

She was born on August 14, 1947 in New York City, New York, U.S. She was the only child of Norma da Câmara Stone dos Reis and John Schulein-Steel. Her parents divorced when she was seven or eight years old. After that, she was reared by relatives and family employees in Paris and New York City. She graduated from the Lycée Français at the age of 15, and in 1963 she enrolled in the Parsons School of Design in New York. Illness prevented her from finishing her studies, but, when she recovered, she married a wealthy French banker. In 1968 she was hired as a vice president of public relations for the advertising agency Supergirls, Ltd., in New York City. When the firm closed in 1971, Steel turned to writing novels and poetry. ${ }^{13}$

First Sight is one of her novels which is released in 2013. In this novel, she adds some of her real-life experiences into the story. This makes First Sight become one of her prolific novels. Steel inserts some of her personal experiences into the story. Inside the novel, the female main character was left by her parents and starting to live in an orphanage when she was still five years

\footnotetext{
11 "Bantam Press," 20-21.

12 "Bantam Press."

13 "The Editors of Encyclopaedia Britannica," Encyclopedia Britannica, accessed July 16, 2021, https://www.britannica.com/editor/The-Editors-of-Encyclopaedia-Britannica/4419.
} 
old. This situation is almost the same as what happened to Steel when she was still five. She has been married five times. She had nine children which eventually dropped to eightbecause one of them, Nick, committed suicide in 1997 at the age of 19. Nick decided to end his life because he could not stand the disease he was suffering from. Steel then wrote a story about her son's struggle into a book entitled His Bright Light: The Story of Nick Traina (1998) and has called it her most personally meaningful book.

Steel uses the characterization of Timmie O'Neill who shows the women needs of men. Steel describes how Timmie still need the love of a man even though she can be considered as a public figure. She still wants to feel domestic, being feminine to the man she loved. This shows that the perspective of Radical feminists tends to be more militant in their approach (radical as "getting to the root") than other feminists. Radical feminist aims to dismantle patriarchy rather than making adjustments to the system through legal changes. Radical feminists also resist reducing oppression to an economic or class issue, as socialist or Marxist feminism sometimes did or does. Radical feminism opposes patriarchy, not men. To equate radical feminism to manhating is to assume that patriarchy and men are inseparable, philosophically and politically. ${ }^{14}$ It is irrelative with the idea of feminism now, where women are treated equally and have their freedom to maintain their femininity. They could go ahead and fall in love with men and marry them while at the same time also maintain their careers.

Danielle Steel agree about the topic that a woman could take both active subject and passive subject. Steel writes in her novel that becoming a working woman doesn't mean she can't have a relationship with a man and have children with them. They could still get married and have children. It is shown in the main character of First Sight novel written by Danielle Steel. Timmie is not only successful and wealthy but she is also want to feel domestic. What I mean as domestic here is the same as the aspects of domestic woman in the past. Woman are expected to be able to do what is called minor arts like cooking, sewing, knitting, and embroidery. In the case where the woman are married and became a mother, she was expected to be able to serve her husband and take care of their children. In the past, all of these aspects are seen as the impact of the patriarchy system but now it is considered as the result of the right of self-expression for women.

\section{Conclusion}

Working women are now a common thing in America. Single women, married women, and even mothers are now working in the same field as men. Being feminine and have domestic aspects in them are now considered to be good. They had the freedom of choices whether to be single or married, finding a job and go to work or become a domestic housewife, or even both at the same time. The thing is, day by day, things, started to change. Gender equality has been achieved, and things in the past are considered as products of men's power are now seen as a value of a good woman, especially a woman on being domestic. They are free on managing their womanliness and femininity. Being a woman and being a man have their plus and minus, and they were created so that woman and man could complete each other.

\section{Acknowledgement}

First of all we would like to deliver our truly gratitude and honor to the greatest Allah SWT for the generosities and the blessings given to us to finish my study. We also would like to

\footnotetext{
${ }^{14}$ Mundelein College B. A. and Meadville/Lombard Theological School M. Div., "What Is Radical Feminism?," ThoughtCo, accessed July 16, 2021, https://www.thoughtco.com/what-is-radicalfeminism-3528997.
} 
give this gratitude to Universitas Jember, faculty of Humanities, especially to the Dean of Faculty of Humanities, the head of English Department, and All of the lectures of English department who have given the valuable knowledge during my academic years of study.

\section{Bibliography}

Blau, F. D. dan Kahn, L. M. 2000. Gender Differences in Pay. Journal of Economic Perspectives, 14(4), 75-100.

Brooks, A. 2003. Postfeminisms: Feminism, Cultural Theory and Cultural Forms. New York: Taylor and Francis e-Library.

Budgeon, S. 2011. The Contradictions of successful feminity: Third-Wafe Feminism, Postfeminism and 'New' Feminities in New Feminities. Postfeminism, neoliberalism, and Subjectivity, edited by Gill, R and Scharf, C. New York:Palgrave Macmillan.

Costa, L.H.R. and Coelho, E.A.C. 2013. Ideologies of Gender and Sexuality: The Interface between Family Upbringing and Nursing Education. Text context nursing. Florianópolis.

Denzin, N.K. and Lincoln, Y.S. 1994. "Introduction: Entering the field of qualitative research." In NK Denzin and YS Lincoln (eds.) Handbook of Qualitative Research. pp. 1-18. Thousand Oaks: Sage.

Foucault, M. 1976. The History of Sexuality. New York : Vintage Book.

Gill, R. 2007. Postfeminist Media Culture: Elements of a Sensibility, European Journal of Cultural Studies, 10(2): 147-66.

Irigaray, L. 1985. Speculum of the Other Woman. New York: Cornell University Press. Translated by Gill, C, G.

Irigaray, L. 1996. I Love to You: Sketch of A Possible Felicity in History. New York : Routledge. Translated by Martin, A

Lewis, J, J. 2020. What is Radical Feminism?. https://www.thoughtco.com/what-is-radicalfeminism-3528997. Accessed on 03 February 2021.

Litosseliti, L dan Sunderland, J. 2002. Gender Identity and Discourse Analysis. City: Publisher

Loscocco, K., \& Bird, S. R. 2012. Gendered Paths. Work and Occupations, 39(2), 183-219. doi: $10.1177 / 0730888412444282$

Morris, W. D. 2012. The Sex Wars Continue: Hung's Postfeminist Debate. Taylor and Francis Group. Department of Mass Communication and Communication Studies. Towson University. Towson. Maryland. USA. Amsterdam/Philadelphia: John Benjamins Publishing Company.

Steel, D. 2013. First Sight. United States: Delacorte Press. Great Britain: Bantam Press. Great Britain: Transworld Publishers. 
The Editors of Encyclopedia Britannica. 2009. Danielle Steel Biography. https://www.britannica.com/biography/Danielle-Steel. Accessed on 17 November 2021. 